Holyk M. M.,

maryholyk@gmail.com,ORCHID ID: 0000-0002-3320-2392,

ResearcherID: P-2999-2016,

Ph.D., Lecturer, Chernivtsi Cooperative College of Economics and Law, Chernivtsi

\title{
TOURISM INDUSTRY OF UKRAINE: CURRENT STATE, PROBLEMS OF DEVELOPMENT AND WAYS OF IMPROVEMENT
}

\begin{abstract}
The article investigates current state, the problems of development and ways of improvement of the tourism industry of Ukraine. The purpose of the article is to analyze the current state of the Ukrainian tourism industry, highlight the key problems of development and determine the ways of improvement of its functioning. The study found that the tourism industry in Ukraine is one of the perspective directions of socio-economic development of the country. It is established that there are all objective prerequisites as favorable geopolitical location, favorable climate, diverse terrain, transport network, historical identity and cultural values of the nation for the development of the tourism industry in Ukraine. Key problems of development of the tourist industry of Ukraine are highlighted and ways of improvement of its functioning are offered, in particular improvement of the state policy of support and regulation in terms of search of potential sources of financial support, optimization of tourist and recreational potential's use of Ukraine's regions, activation of informational and analytical support at the regional, national and international level. All of this will help to increase the national and local budget revenues, number of potential jobs and investments in the domestic economy. Further research should be directed towards a more complete study of the organizational and economic aspects of the functioning of the tourism industry in Ukraine.
\end{abstract}

Keywords: tourism, tourist industry, tourist flows, current state, problems of development, ways of improvement.

Голик M. M., maryholyk@gmail.com, ORCHID ID: 0000-0002-3320-2392,

Researcher ID: P-2999-2016,

к.е.н., викладач, Чернівецький кооперативний економіко-правовий коледж, м. Чернівиі

\section{ТУРИСТИЧНА ГАЛУЗЬ УКРАЇНИ: СУЧАСНИЙ СТАН, ПРОБЛЕМИ РОЗВИТКУ ТА ШЛЯХИ ВДОСКОНАЛЕННЯ}

\begin{abstract}
Анотація. У статті досліджуються проблеми розвитку та иляхи вдосконалення туристичної галузі України. Метою статті є аналіз сучасного стану туристичної галузі Украӥни, виділення ключових проблем розвитку та визначення шляхів вдосконалення ї функціонування. У ході дослідження встановлено, щзо туристична галузь в Україні є одним із перспективних напрямків соціально-економічного розвитку держави. Встановлено, щзо для розвитку туристичної галузі в Україні існують усі об'єктивні передумови: вигідне геополітичне розташування, сприятливий клімат, різноманітний рельєф, мережа транспортних сполучень, історична самобутність та культурні иінності нації. Виокремлені ключові проблеми розвитку туристичної галузі України та запропоновані шляхи вдосконалення ї̈ функиіонування, зокрема удосконалення державної політики підтримки та регулювання у частині пошуку потенційних джерел фінансового забезпечення, оптимізації використання туристично-рекреаційного потенціалу регіонів Украӥни, активізації інформаційноаналітичного забезпечення на регіональному, національному та міжнародному рівнях. Все ие сприятиме зростанню грошових надходжень до загальнодержавного та місиевих бюджетів, збільшенню кількості потенційних робочих місць, активізаџії інвестицій у вітчизняну економіку. Подальші дослідження повинні бути спрямовані на більш повне вивчення організаційно-економічних аспектів функціонування туристичної галузі Украӥни.
\end{abstract}

Ключові слова: туризм, туристична галузь, туристичні потоки, сучасний стан, проблеми розвитку, шляхи вдосконалення.

JEL Classification: L83, M21

DOI: https://doi.org/10.36477/2522-1205-2019-58-07

Target setting. For today, the tourism industry is at least third among the sectors of the world economy in terms of income and it is one of the perspective directions of socio-economic development of the 
country. In many European countries, tourism is the main source of income and revenue. So, worldwide tourism business revenues are totally more than $\$ 500$ billion annually [8].

Since the Declaration of Ukraine's independence was proclaimed, the domestic tourism industry began to develop actively. Now, tourism is one of the most perspective sectors of the national economy, where approximately $10 \%$ of our country's population involved. However, according to investigations of analysts, the share of tourism in the GNP of Ukraine is still less than $2 \%$, despite the fact that in developed countries this indicator ranges from 5 to $8 \%[1$, p. 84].

In such circumstances, it is up to date the need to study more deeply the current state of the Ukrainian tourism industry in the national economy, its development in the conditions of globalization and internationalization (because of the problems related to the scale of tourist companies activity and expansion of territorial borders) and management (in the context of improving the efficiency and profitability of tourism organizations).

Actual scientific researches and issues analysis. The issues of the development of the tourism industry as one of the most perspective directions of the country's economy were investigated by such domestic scientists as O. Bartoshchuk [1], O. Bespala [2], Z. Gerasymchuk [3], V. Kifyak [4; 5], T. Ryabova [8], I. Shamara [10], etc. At the same time, in the context of intensifying the population interests in obtaining cultural and historical tourism services, the complex theoretical questions which are devoted to the scientific rethinking of the features of formation the modern tourist industry of Ukraine require the further deeper development.

Research objective. The purpose of the article is to analyze the current state of the Ukrainian tourism industry, highlight the key problems of development and determine the ways of improvement of its functioning.

Statement of basic materials. Although the tourism industry is a key priority direction for the growth of the domestic economy, the unstable political and economic situation in Ukraine has a very negative impact on the further advance development of the tourism business. The current situation in the country discourages potential foreign investors who would like to invest in the development of tourist and recreation complex. That is why, in order to improve the situation, first of all it is necessary to conduct wellconsidered economic, informational and state policies which aimed at creating a positive image of Ukraine as competitive country in the field of travel and tourism.

It is necessary to note that there are all objective prerequisites for the development of the tourism industry in Ukraine. First of all, it is worth to mention about the favorable geopolitical location, considerable recreational potential, in particular favorable climate, diverse relief, the network of transport connections, historical identity and cultural values of the nation. In addition, for today the hotel and restaurant infrastructure is being actively developed, the quality of tourist services is being improved because of increasing the level of theoretical and practical training of the service staff, the attendance of tourist sites is increasing, and fundamentally new tourist routes are emerging.

As a result, these prerequisites contribute to the dynamic development of the tourism industry in our country, which is confirmed by the analysis of tourist flows, graphically presented in Fig. 1.

According to Fig. 1 for the period from 2013 to 2014 years in Ukraine there was the decrease in the value of both indicators as the number of Ukrainian citizens who went abroad (in 2014 by 1323616 persons or by $5.57 \%$ compared to 2013) and the number of foreign citizens, who visited Ukraine (by 11959720 people, or by $48.48 \%$ during the same period). It is primarily due to the impact of political events in the eastern Ukraine, which negatively affect the overall situation in the country, both inbound tourism and outbound tourism.

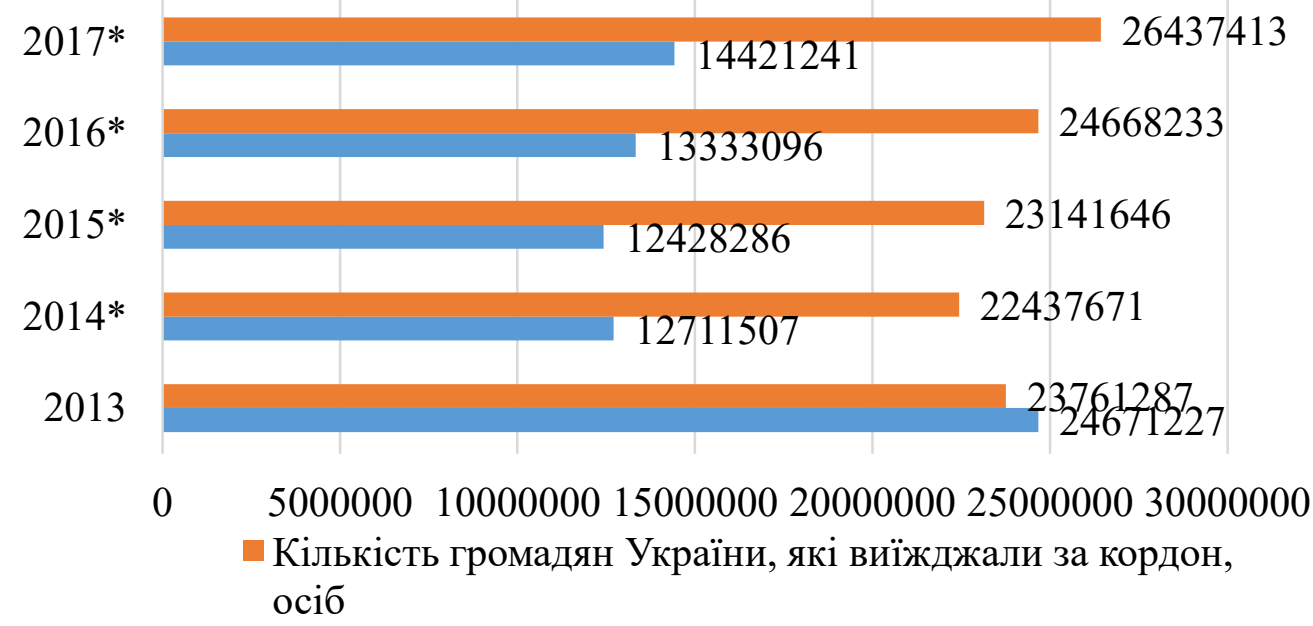

Fig. 1. Dynamics of tourist flows in Ukraine for 2013-2017 years [9]*

* without taking into account the temporarily occupied territories of the Autonomous Republic of Crimea, the city of Sevastopol, and part of the temporarily occupied territories in Donetsk and Luhansk regions. 
Since 2014, the value of the number of Ukrainian citizens who travelled abroad has shown an increasing trend (in 2017 by 3999742 persons, or $17.83 \%$ compared to 2014), which certainly has a positive effect on the overall situation of the tourist industry in Ukraine.

On the other hand, since 2015 the number of foreign citizens who visited Ukraine is gradually increasing, but even in the last 2017 year this indicator was less by 10249986 persons, or by $41.55 \%$ compared to 2013 and only more by 1709734 persons, or by $13.45 \%$ compared to 2014 . We believe that the main reason for the decrease in the value of the number of foreign citizens who visited Ukraine is, first of all, the unwillingness of foreign tourists to visit a politically unstable country, which, therefore, significantly complicates the conduct of tourist activity in Ukraine and hinders the further development of the tourism industry in Ukraine.

In 2013-2017, the distribution of tourists served by tourist operators in Ukraine indicates the decrease in the number of foreign citizens who visited Ukraine (by $5.32 \%$ in 2017 compared to 2013) (Table 1). At the same time, it was reflected in the number of Ukrainian citizens who traveled on the Ukraine's territory (this indicator decreased from $20.34 \%$ to 17.00 in 2017 compared to 2013). Instead, during 2013-2017 the share of tourists and citizens of Ukraine who went abroad increased from $72.93 \%$ in 2013 to $81.59 \%$ in the last 2017. We believe that during this period the increase in outbound flows of Ukrainian tourists is due to the fact that Ukrainian citizens have stepped up trips to the neighboring countries (Russia, Poland, Moldova, Hungary, Belarus, Slovakia) because of labor migration.

In general, the analysis of tourist flows of Ukraine for 2013-2017 years shows the importance of the development of inbound and outbound tourism, which is an important factor of the development of the national economy by creating additional jobs, replenishing the country's foreign currency reserves and enhancing its positive image in the international arena.

With the aim of intensifying the development of the tourism industry and increasing the efficiency of tourism organizations, today it is important to solve the problems that require balanced state support and regulation.

The main problems which hindering the further development of the tourism industry in the country are [8]:

- instability of the political situation in the country and the presence of military conflict in the East of Ukraine;

- disadvantages of regional regulation of the tourism industry;

- insufficiency of advertising information about tourist attractiveness of Ukraine abroad;

- high tax burden, which is an obstacle for potential investors to invest in the tourism industry;

- insufficient level of staff qualification of the tourism industry;
- a small number of hotels that meet the world standards.

We believe that this list of obstacles is inexhaustible and requires some additions. Thus, we see a significant gap in the imperfect state policy of support and regulation of the tourism industry in terms of establishing partnerships with the private sector of the national economy.

Apart from the above mentioned problems of tourism development in Ukraine, the weak tourism infrastructure remains especially acute. In particular, the modernization of railways and motorways throughout Ukraine, the expansion of existing flights and, accordingly, the construction of new innovatively equipped airports in regional centers are required.

So, despite the considerable resource potential, the tourism industry of Ukraine has a number of significant gaps, which requires the identification of effective ways of improvement. Analyzing the prospects for the development of the tourism industry in Ukraine, it is worth to note that the modern tourism industry is a factor in the growth of the national economy and the well-being of its population, which integrates almost all industries. We believe that this should become decisive in the formation of a new state policy of support and regulation in the field of tourism, the priority of development of which should positively affect the socio-economic position of the country, contribute to strengthening its positive image in the world.

For the advance development of the tourism industry of Ukraine let us to identify the following ways of improvement of its functioning:

- to direct the development of the tourism industry of Ukraine in the way of rational use of resources and preventing their long-term depletion;

- to take into account the requirements for environmental protection through cost-effective environmental regulation and active cooperation of countries at the global, national, regional and local levels [3, pp. 68-69];

- to improve the legal support, in particular to input the structural amendments to the Law of Ukraine "On Tourism" and "Resolution of the Cabinet of Ministers of Ukraine "On approval of the Tourism and Resort Development Strategy for the period up to 2026 " on issues of the public relations regulation in the field of tourism and ensuring the safety of foreign and domestic tourists, as well as domestic tourists, who travel abroad;

- to expanse the financing sources for the development of the tourism industry, including through the activation of state financing, foreign direct investment, stock market instruments and bank lending;

- to develop the national information and analytical system in the field of tourism and its integration into the world information tourist network;

- to improve the business climate in the tourism industry and to promote the fair competition;

- to develop the new tourist territories in Ukraine, etc. 
Distribution of tourists served by tourist operators of Ukraine for 2013-2017 years [9]

\begin{tabular}{|c|c|c|c|c|c|c|c|c|}
\hline \multirow[b]{2}{*}{ Years } & \multirow[b]{2}{*}{$\begin{array}{l}\text { The number of } \\
\text { tourists served by } \\
\text { tourist operators of } \\
\text { Ukraine, persons }\end{array}$} & \multirow{2}{*}{ 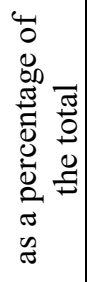 } & \multicolumn{6}{|c|}{ Including } \\
\hline & & & $\begin{array}{l}\text { Foreign } \\
\text { tourists, } \\
\text { persons }\end{array}$ & 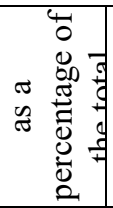 & $\begin{array}{l}\text { Tourists and } \\
\text { citizens of } \\
\text { Ukraine who } \\
\text { went abroad, } \\
\text { persons }\end{array}$ & 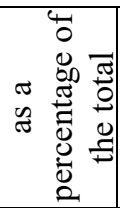 & $\begin{array}{l}\text { Domestic } \\
\text { tourists, } \\
\text { persons }\end{array}$ & 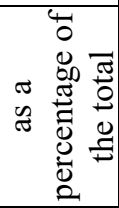 \\
\hline 2013 & 3454316 & 100 & 232311 & 6,73 & 2519390 & 72,93 & 702615 & 20,34 \\
\hline 2014 & 2425089 & 100 & 17070 & 0,70 & 2085273 & 85,99 & 322746 & 13,31 \\
\hline 2015 & 2019576 & 100 & 15159 & 0,75 & 1647390 & 81,57 & 357027 & 17,68 \\
\hline 2016 & 2549606 & 100 & 35071 & 1,38 & 2060974 & 80,83 & 453561 & 17,79 \\
\hline 2017 & 2806426 & 100 & 39605 & 1,41 & 2289854 & 81,59 & 476967 & 17,00 \\
\hline
\end{tabular}

Conclusions and prospects of further research in this direction. So, nowadays the tourism industry of Ukraine is one of the priority factors for the growth of the national economy. It should be emphasized that the tourism industry contributes to the growth of national and local budget revenues, the increase of the number of potential jobs, the activation of investments in the domestic economy.

As a result of the analysis of the current state of the tourism industry in Ukraine and the identification of its key development problems, it can be concluded that for today it is expedient to improve the state policy of support and regulation in terms of finding potential sources of financial support, optimizing the use of tourist and recreational tourism potential of Ukraine's regions, activation of informational and analytical support at regional, national and international levels. The prospect of further exploration in this direction is a deeper study of the organizational and economic aspects of the tourism industry functioning in Ukraine.

\section{REFERENCES}

1. Bartoschuk, O. V. (2012), Assessment of tourism development in Ukraine, Investytsii: praktyka ta dosvid, vol. 7, pp. 82-86.

2. Bespala, O. A. (2017), Current state, problems and prospects of development of the tourist market in Ukraine, Ekonomika: realiyi chasu, vol. 6 (34), pp. 917 , URL: https://economics.opu.ua/files/archive/2017/No6/9.pdf (Accessed 21 October 2019).

3. Herasymchuk, Z. V. (2008), Rehional'na polityka staloho rozvytku : teoriya, metodolohiya, praktyka [Regional policy of sustainable development: theory, methodology, practice], Nadstyr'ya, Luts'k.

4. Kyfyak, V. F. (2003), Orhanizatsiya turystychnoyi diyal'nosti $v$ Ukrayini [Organization of tourist activity in Ukraine], Knyhy-XXI, Chernivtsi.

5. Kyfyak, V. F. (2015), Development of tourism as one of the scenarios for improvement of socioeconomic status of Chernivtsi region, Turyzm, vol. II (58), pp. 67-81.

6. Cabinet of Ministers of Ukraine (2017), Resolution of the Cabinet of Ministers of Ukraine «On approval of the Tourism and Resort Development Strategy for the period up to 2026» URL: https://zakon.rada.gov.ua/laws/show/168-2017$\%$ D1\%80 (Accessed 21 October 2019).

7. The Verkhovna Rada of Ukraine (1995), The Law of Ukraine "On tourizm", URL: https://zakon5.rada.gov.ua/laws/show/324/95$\% \mathrm{D} 0 \% \mathrm{~B} 2 \% \mathrm{D} 1 \% 80$ (Accessed 21 October 2019).

8. Ryabova, T. A. (2018), State and prospects of tourism industry development in Ukraine, Efektyvna ekonomika, [Online], vol. 4, URL: http://www.economy.nayka.com.ua/pdf/4_2018/51.pdf (Accessed 21 October 2019).

9. The official site of State Statistics Service of Ukraine (2017), Tourist streams, URL: http://www.ukrstat.gov.ua/operativ/operativ2007/tyr/ty r_u/potoki2006_u.htm (Accessed 21 October 2019).

10. Shamara, I. M. and Azarova, K. I. (2018), The current state, problems and prospects of development of the tourist services market of Ukraine, Visnyk KHNU imeni $V$. N. Karazina. Seriya "Mizhnarodni vidnosyny. Ekonomika. Krayinoznavstvo. Turyzm», vol. 3, pp. 196-203.

\section{ЛІТЕРАТУРА}

1. Бартощук О. В. Оцінка розвитку туризму в Україні / О. В. Бартощук // Інвестиції: практика та досвід. - 2012. - № 7. - С. 82-86.

2. Беспала О. А. Сучасний стан, проблеми та перспективи розвитку туристичного ринку в Україні / О. А. Беспала // Економіка: реалії часу. Науковий журнал. - 2017. - № 6 (34). - С. 9-17. URL: https://economics.opu.ua/ files/archive/2017/ No6/9.pdf (дата звернення: 21.10.2019).

3. Герасимчук 3. В. Регіональна політика сталого розвитку: теорія, методологія, практика : монографія / 3. В. Герасимчук. - Луцьк : Надстир'я, 2008. -528 c.

4. Кифяк В. Ф. Організація туристичної діяльності в Україні : навч. посіб. / В. Ф. Кифяк. Чернівці : Книги-XXI, 2003. - 300 с.

5. Кифяк В. Ф. Розвиток туризму, як один зі сценаріїв покращення соціально-економічного 
Вісник Львівського торговельно-економічного університету. Економічні науки. № 58, 2019

стану Чернівецької області / В. Ф. Кифяк // Туризм. - Випуск II (58). - 2015. - С. 67-81.

6. Про схвалення Стратегії розвитку туризму та курортів на період до 2026 року : Розпорядження від 16 бер. 2017 p. № 168-p. URL: https://zakon.rada.gov.ua/laws/show/168-2017\% D1\%80 (дата звернення: 21.10.2019).

7. Про туризм : Закон України від 15.09.1995 p. № 324/95-BP URL: https://zakon5.rada.gov.ua/ laws/show/324/95-\%D0\%B2\%D1\%80 (дата звернення: 21.10.2019).

8. Рябова Т. А. Стан та перспективи розвитку туристичної галузі в Україні / Т. А. Рябова // Ефективна економіка. - 2018. - № 4. URL: http://www.economy.nayka.com.ua/pdf/4_2018/51.pdf (дата звернення: 21.10.2019).
9. Туристичні потоки. Державна служба статистики України : веб-сайт. URL: http://www.ukrstat.gov.ua/operativ/operativ2007/tyr/ty r_u/potoki2006_u.htm (дата звернення: 21.10.2019).

10. Шамара I. М. Сучасний стан, проблеми та перспективи розвитку ринку туристичних послуг України / I. М. Шамара, К. I. Азарова // Вісник ХНУ імені В. Н. Каразіна. Серія «Міжнародні відносини. Економіка. Країнознавство. Туризм». 2018. - Вип. 3. - С. 196-203.

Стаття надійила до редакиії 6 листопада $2019 p$. 